\title{
Of Mice and Masks: How Performing Citizenship Worked for a Thousand Years in the Venetian Republic and Why the Age of Enlightenment Brought it to an Abrupt End
}

\author{
Mirjam Schaub
}

\section{INTRODUCTION}

While the plague raged in 14th century Venice-eradicating countless patrician families, who were what kept the Maritime Republic alive with its unique system of office rotation and power distribution-the Venetians reinvented their endangered community and polity, with the help of a uniform white mask (larva or volto), a black hood and a three-pointed hat.

Presumably, it was in protest against the Black Death-that killed rich and poor without exception-that this so-called maschera nobile or baut $\grave{a}^{1}$

Translated from German by Alice Lagaay

\section{Schaub $(\bowtie)$}

University of Art and Design Burg Giebichenstein, Halle a.d. Saale, Germany

(C) The Author(s) 2019

P. Hildebrandt et al. (eds.), Performing Citizenship, Performance Philosophy, https://doi.org/10.1007/978-3-319-97502-3_16 
was first borne. But it soon developed into a powerful social equalizer, for it permitted the Venetian Republic to regard its own police and spy state as necessary interventions in the fight against corruption and, at the same time, allowed its citizens to lead a relatively untroubled life beyond convention and constraints. As a social mask, the bautà grew in popularity between the 14th and 18th centuries, and it played a role at almost every public occasion, as can be seen in countless Canaletto, Longhi and Guardi paintings. Above all, it revolutionized social life by allowing a simple form of anonymization, thus guaranteeing Venetian citizens of both sexes libertine, even voluptuous, practices while respecting etiquette.

The mask reflects the richness of Venetian social and political inventions. The Venetians did not believe in the good of man, which is one of the reasons why the republic survived a thousand years of crusades and slaughter but not the century of enlightenment. Instead, the Venetians believed in institutions, in imposing restrictions to control unwelcome human behaviour. They racked their brains over procedures that would prevent human beings from choosing the easy way. Acknowledging the fact that destroying and doing harm was simple in comparison to the difficulties of re-installing trust and credibility, they invented sophisticated practices and countless precautions from which they expected more benefits and practical wisdom. They had little expectations of weak-but only too corruptible-human beings.

The success of the Venetian Republic depended on its profound pessimism, its distrust in human goodness. Instead of wanting to change the nature of man, say, by affirmative self-declaration, it created a system of procedural interventions and institutional coups whose purpose was to counteract abuse and corruption, like a corset used to fight formlessness.

In the context of a book on 'Performing Citizenship' that focuses rather on contemporary problematizations, the horizon of this essay suggests a new perspective from which contemporary citizens and civil rights movements might perhaps reconsider their usual form of general institutional critique by drawing inspiration from the inventiveness with which historical Venice sought to limit abuses of power, using institutional means and procedures.

Admittedly, the richness of their inventiveness was triggered by a negative image of humanity that Napoleon was not alone in considering premodern and hostile to reason. But in this regard, one might ponder whether our 'enlightened' and idealized image of mankind might not actually be its own comeuppance when accusations of misconduct are directed at a few 'black sheep', instead of the tendency for misconduct 
being recognized as a conditio humana. The Venetian Republic-which subsisted for a thousand years (from around 797 to 1797) without any means of providing for itself except through clever trade-relied heavily on the quick undermining of any suggestion of corruption.

This constellation allowed the citizens of Venice to consider control and freedom of movement, spying, libertinage, and veneration not as opposites, but rather, as reciprocal fires in the expression of their unique concept of performing citizenship. That their political inventions be considered pre-modern or anti-enlightened would appear, as shall be shown, to be based on historical prejudice and is therefore in urgent need of revision.

\section{Office Rotation and the Distribution of Power}

After the deliberate closing (serrata) of the politically powerful 'caste' and its limitation ${ }^{2}$ to old, established, aristocratic families in 1297, the ideal of ruling among equals was faced with the problem of balancing power and control by the same permanent staff.

The republic could not tolerate being steered (from political responsibility) by the idle. Not even impoverishment was considered an acceptable excuse for the non-fulfilment of aristocratic duties. Little more than two hundred families, who had inhabited the lagoon for generations, were involved in creating the cautious laws of the republic. According to these laws, only male aristocrats over 25 years of age, who had gone to university in Padua $^{3}$ or become bowmen to the galleys, were entitled to take over the legislature and the judiciary of the Republic of Venice. The republic kept a turnstile of official jobs that rotated between a fixed number of noble families. No official position was to be occupied for more than 12 or 18 months.

Interestingly, it was their deep and constantly evolving knowledge of real, banal and all-too-human weaknesses that explains why political selfdetermination, trafficking, cunning, scrutiny and libertinage were so closely intertwined in Venice as to become indistinguishable. Seen in this light, Giacomo Casanova's escape from the lead chambers of the Doge's Palace succeeded not only thanks to the intervention of senator Matteo Giovanni Bragadin, but also due to the impersonal program, which emerged from the unique political self-understanding of the Venetian Republic. ${ }^{4}$ What if the republic had imprisoned Casanova in 1756 , only to let him flee after 15 months, in order to make him return later as a gifted and devoted spy for the flourishing Venetian commonwealth? 


\section{How to Avoid Corruption When Everyone Is Corruptible?}

Instead of identifying inequality as a disadvantage, Venetian politics were purposefully set out to overcome a scandalous form of equality that was considered a threat to society. For it was the long-anticipated equality of all members of the Venetian society, regarding their common corruptibility, which led to a unique political alliance. This alliance concerned the precautions necessary to undermine or disarm any pseudo-reasons for bribery, such as general distrust in the public order, people's likelihood to choose the paths of least resistance, or clandestine compensation for inadequacies and injustices, and so on.

The chosen method was to organize all social classes-patricians, commoners, craftsmen, soldiers-from the point of view of their similarities, in order to secure a lasting base for social peace. This was achieved by introducing independent organizations such as the guilds (from the retailer to the card-maker, from the soap-maker to the mascot maker or goldsmith), from which strong, secular fraternities (scuole) derived. Their leading members henceforth wore the costume of the patricians (toga veneta). The chairman of the fishermen's guild even took his seat as 'Doge of the pescatori' next to the noble Doge during the annual processionFesta della Sensa or Festa dell'Ascensione - to celebrate the symbolic marriage between the city and the sea.

Thus, even those who had no political decision-making power were still able to participate in the symbolic chain of power transmission. Venetian society worked much like a Märklin railroad according to the principle of miniaturization, whereby train compartments with varying levels of comfort ran and rattled without disturbing each other's circuits. While the noble patricians constantly changed their offices, the cittadini-commoners or civics - ensured continuity by dealing with the administrative offices of the executive.

The bourgeois Grand Chancellor of the republic, appointed as the chief executive for life, was the only Venetian not to bow before the noble Doge. He was privy to all the secrets of the state but had no right to vote or speak in any council. The coats of arms of the 45 bourgeois Grand Chancellors that ruled Venice between 1297 and 1797 were placed prominently on the walls of the Doge's Palace, as were the Doges' portraits in the marble section - albeit locked away in a wooden cabinet, hidden to the eyes of ordinary visitors. If, since 1315, the hand-painted coats of arms of 
the noble families and their names were collected in the Golden Book of the City, then the citizens' names were to be found in the Book of Silver. Each social class mimicked the rituals and privileges of the class above them in the stato misto of Venice, reflecting them while introducing slight differences. This ensured the satisfaction of all and established a degree of distance built on familiarity.

Given the small number of staff members that had known each other for generations, abuse of authority in Venice was never considered to be the unfortunate affair of a few 'black sheep'. Quite the contrary, corruption was exactly what was expected of everyone all the time.

Venetians were such pessimists that, by 1275 , they had invented an elaborate system of precautionary measures. It consisted of a wellorganized mixture of personal votes and impersonal lotteries, alternating between random, intuitive and strategic decisions and supplemented by prescribed interruptions of office that sometimes lasted as long as the office itself. Thus, for a thousand years, all urgent or controversial political tasks rotated successfully among the male, adult members of only 204 different patrician families (case vecchie), without a single family ever gaining too much power. ${ }^{5}$

Thus, corruption was prosecuted forcefully, and the misuse of power often resulted in expropriation and exile. In order not to be suspected of corruption, local traders in Venice were not allowed to put foreign merchants up in their houses, nor allowed-under any circumstance-to accept any gifts. ${ }^{6}$ Those operating outside the republic, if suspected of mischief, would immediately be brought back to Venice, imprisoned in the Doge's Palace's wet pozzi and, later, publicly executed. Thus, an example was set between two bloodthirsty pillars of the Loggia of the Doge's Palace, installing a strong and close-knit network of mutual control, fear and retaliation.

\section{Participation and Exclusion Within the Doge's PALACE}

Thus, in the Doge's Palace of Venice in the 14th century, ideas of political participation and exclusion became both effectively and architecturally visible, that remain to this day uniquely radical in the history of Europe: the political inclusion of many (within the patrician republic), and the simultaneous exclusion of almost all (by the police and spy state), coexist as equally welcomed powers, in peaceful harmony and great spatial proximity. 
After two devastating fires (1574 and 1577), and on the ruins of a 12th-century citadel built without a defence system, the bells of the Trotteria of the campanile of St. Mark's Cathedral would ring out on Sundays and the electoral patricians would gather in the Sala of the Great Council (Maggior Consiglio) within the renovated Doge's Palace. The whole palace itself can in fact be considered as no more than a pretext to have built a space of this magnitude ( 55 by 25 metres) with the capacity for so much participatory impetus. The ceiling seems to float, unsupported by columns. Venetian carpenters simply erected an inverted ship's hull over the gigantic ceiling to absorb the weight of the sides. If you look closely, you can still see how many rusty nails penetrate the ceiling-and its bombastic paintings - in order to make the construction safe. ${ }^{7}$

Thanks to the repeated reduction of the electorate by means of a lottery and the steady reconstitution of numbers through numerous rounds of deliberation, the system-which was especially designed to install the Doge for life as the highest representative of the republic-was indeed hellishly complicated but, ultimately, exceptionally fair. Five times the lottery would decide, five times the electors would debate the pros and cons of the remaining candidates. Since it was impossible to predict whether or not one would still be a member of the electoral college at the end of ten rounds, pre-arrangements were simply hopeless.

In this bombastically magnificent room-modestly called the room of the 900 - not only the Doge, but also the sixty senators, the nine treasurers (procuratores) and all the important offices were elected. It was also the venue for special ceremonies, such as the occasion of Morosina Grimani's inauguration to the office of the Dogaressa (1597), and the place where the Venetian ambassadors would present their reports on the world beyond the lagoon. These reports, the so-called relazioni, were famous for their considerable accuracy, since only an exact study of the gestures and states of mind of driving forces could be used to predict the future plans of action by foreign peoples with some certainty. These portrayals by Venetian diplomats had to be written and stored in the archives where, still today, they remain a fruitful source of information. Clandestinely, Venetians celebrated themselves as clever traders and as equally clever informers, which guaranteed the lasting mastery of la serenissima, the most illustrious republic. By refraining from judgement for the sake of precise descriptions, the reports were so insightful, that they even became much admired-and envied-by foreign powers. 
Fig. 1 Giovanni Bellini, Doge Leonardo Loredan (after 1501), oil on tempera on poplar wood, $61.6 \times 45.1 \mathrm{~cm}$, National Gallery, London

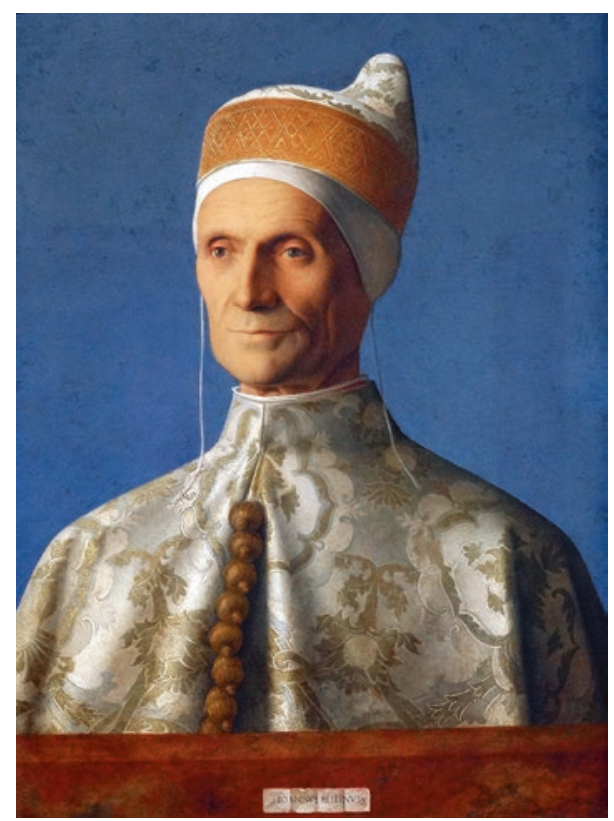

The art of reading minds through studying the characteristics of facial features, and the knowledge of how to index and interpret the slightest show of emotion, belonged, as it were, to early childhood education in the Venetian Republic. It was in Venice, not Florence, that the art of portraiture was born, with the Bellini brothers, Giorgione, and later Titian and Tintoretto. Precisely because the exhibition of Venetians was strictly forbidden in public places, patricians and wealthy citizens first began to commission portraits for themselves for private display only. Even the Doge was only allowed to have his portrait painted for his own private collection, like Leonardo Loredan—painted by Giovanni Bellini after 1501 (Fig. 1).

In the narrow streets of Venice, it was essential to always know exactly whom one might encounter by chance, and to be able to greet them by name and actual status - no easy task given the annual office rotation. To solve this problem, the Venetians invented an unconventional and effective solution: the mask. 


\section{The Venetian bautà: A Social Mask and Its Multiple FunCTIONS}

Of course, the masks in question differed from the ones people are most familiar with now. Not the traditional, colourful carnival masks of harlequin, lawyer, dottore or capitano (since the late Middle Ages), nor the grotesque half masks of the actors of the commedia dell'arte (since the 16th century); these were used to emphasize character, or exaggerate certain features, they did not primarily serve to anonymize. The austere white mask that is meant here is often depicted in the paintings of Canaletto (1697-1768), Pietro Longhi (1702-1785) and Francesco Guardi (1712-1793). ${ }^{8}$ In allowing a person to look dignified and yet unrecognizable as a particular person in the middle of the public sphere, the so called bautà enabled its bearer to mind his or her own business. Visible but opaque, singular but anonymous, the mask would allow the person to disappear in the crowd, like a black dot with a white stipple.

In terms of external appearance, this type of mask complemented the traditionally black, ankle length coat (tabarro) of the Venetian merchants. The whole outfit consisted of five garments and accessories: a black hood (bautà), a silk chest cape, a short gown of black gauze, a three-pointed hat and a white larva for the face. The larva was placed over the chin but pointing sharply upwards so that the person could eat and drink whilst remaining unrecognizable under the mask. For brevity, this mask was commonly referred to as bautà in its entirety and compiled with the tabarro. It became appropriate for both men and women. In fact, it soon became impossible to tell whether a woman or a man was wearing it, because the clothes hidden under the long cloak became yet another opportunity to dress up in disguise.

This mask was invented by the nobles but was soon no longer restricted to them. Although it started as a maschera nobile, its overwhelming popularity gradually made it into a social mask. ${ }^{9}$ It was worn outside the carnival season for every conceivable social occasion-in the streets, at weddings, banquets, processions, during elections, theatrical and theatre shows, indeed, even in honour of the Indian rhinoceros Clara (Fig. 2). ${ }^{10}$

In the simplest way, the bautà made it possible for people-who otherwise knew each other perhaps all too well-to become inconspicuous, unidentifiable and equal. What a relief it must have been to have been able to pass unidentified in the small republic, whose entire social realm otherwise depended on one presenting the appropriate attitudine and 


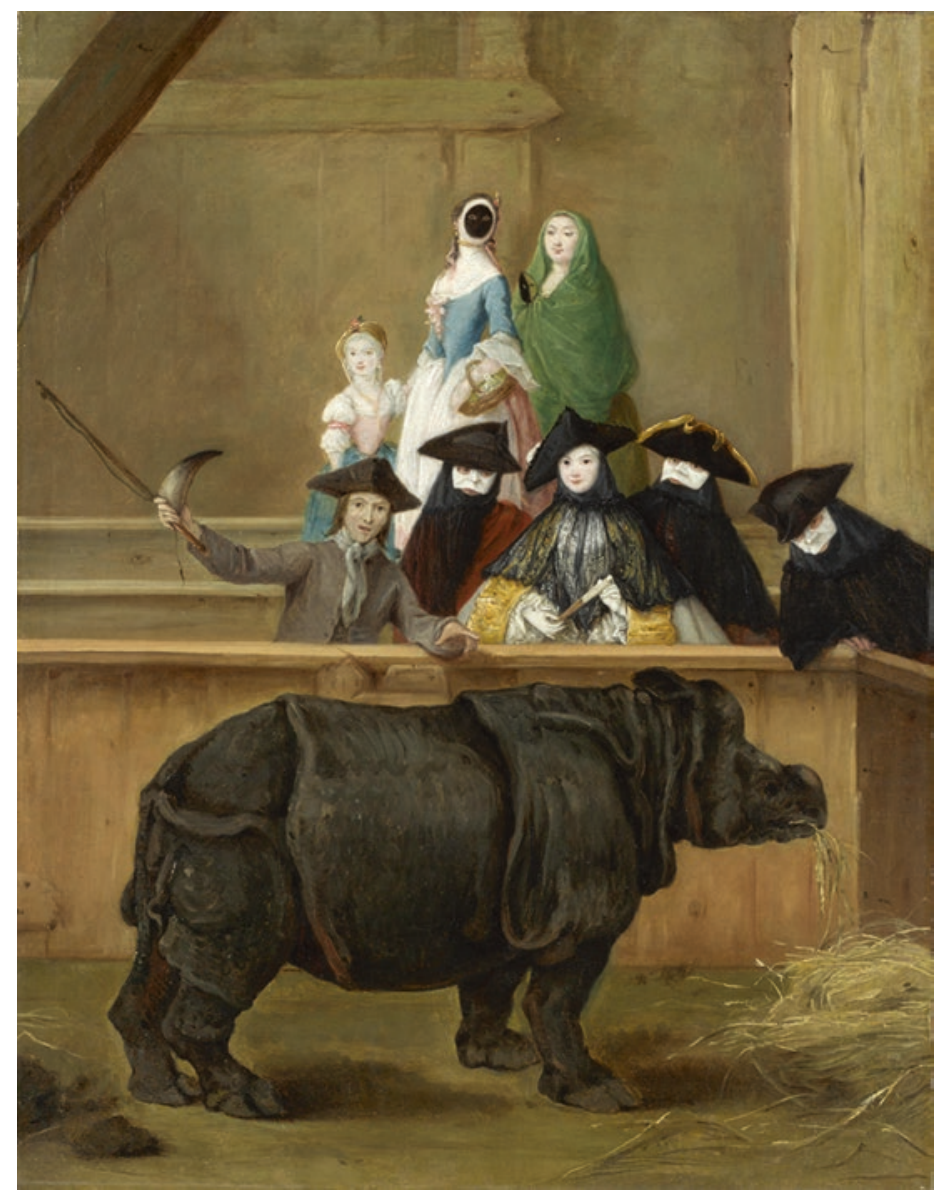

Fig. 2 Pietro Longhi, Exhibition of a Rhinoceros at Venice (1751), oil on canvas, $60.4 \times 47 \mathrm{~cm}$, National Gallery, London

contegno - the right facial expressions and dignified physical postures. The purpose of this mask was not to facilitate role-finding or roleplay, but to allow for distance and anonymity. Even one's voice would sound strange and hard to place, darkly sonorous, when resonating from under the leather mask. Whoever encountered such a masked person on the street would certainly have had to bow to them and say, 'Hail, honorable mask' ('Siôra, Maschera'). 
Exclusive to Venice, the precise origins of this social mask still lie in the dark. In the context of the gruesomely raging pestilence of 1348 , one might plausibly imagine that it came about as an alliance between forces of nature and the morbid pleasure people got from blurring differences of rank. The chronicler Lorenzo de Monacis notes a few years after the events,

Right at the beginning of this plague, within a few days, [it] removed leading figures, judges, and civil servants who had been elected to the Grand Council, and then those who had taken their place. In the month of May it increased so much, and the contagion became so strong that the squares, courtyards, tombs, and cemeteries filled with corpses. ${ }^{11}$

Tens of thousands died within a few months; Dorsoduro, Santa Croce and Cannaregio were basically depopulated. In June 1348, the Grand Council was unable to grant resolutions, due to the loss of most of its members. However, what remained of the Senate continued to rule: ordering quarantine, forbidding alcohol, and even banning the wearing of mourning clothes in an attempt to raise the general mood. Meanwhile,

...the moderates, the restrained, the chaste, the sober, died as the drunks and the sluggishers died, the frugal and extravagant, the bold and timid, those who fled, as well as those who remained behind, all without confession and the sacraments of the Church. Even the pious clerics and priests were seized with horror, and the plague also killed them. The whole city was a grave. ${ }^{12}$

The uniformity of death stifled one particular ritual of the nobles, dating back to the Roman Republic, which was the ritual of taking death masks from the deceased. They would normally wear the masks of their ancestors-who otherwise were on display in the atrium-at each funeral. It is thus conceivable that the uniform larvae of the white bautà arose out of the nobles' growing protest against these restrictions during the first plague. Indeed, to this day, the mask still looks like the unfinished, raw prototype of a mask. Such a presumed origin, in line with the gloomy veneration of the whole appearance, would also explain why the bautà was traditionally worn outside the carnival season. The first plague broke out in Venice at the end of March 1348, and only receded in the late summer of that year. 
Ignazio Toscani-who in the 20th century dedicated a monograph to the bautà-argues that its success, its uncanny popularity, was due to the versatility of its use and the ambiguity of its functions. He suggested that the bautà compensated for the experience of social constriction by providing anonymity as protection. It transcended the finesse of the envoys, in the same ways as Venetian portraiture did, by promising relief from reciprocal facial examination. At the same time, it allowed for secret scrutiny of others under the protection of one's own mask. It thus respected the Venetian code of modesty, in that it appeared as a sign of pure honourable value. It equalized what was different (people and their class), and thereby neutralized what might otherwise be considered a cause for enmity (the mask as a uniform). It protected one against blackmail (as in the case of the election to be held publicly in St. Mark's Square) and when facing one's creditors; indeed, it helped one not lose face in any circumstance. A good example can be seen in the case of public begging, which was in fact not a rare occurrence, for there were many impoverished patricians who were obliged to fulfil their political duties nevertheless. The Venetian social mask was, in short, an institution of far-reaching socially equalizing potential, reconciling the particular with the general, or anonymous and the general, or anonymous with the particular.

The Venetians discovered the virtue of anonymity; that it need not be considered as a threat, but as protection, a promise. They understood that from under the appearance of equality, diversity and a variety of desires could in fact blossom and flourish. It can thus be seen as a kind of logical counterpart to the territorial and social constraints, which, combined with the limitations brought about by the presence of the sea and the closed nature of the different social classes, but at the same time guaranteed the extraordinary liberties that characterized Venice (both inwardly and outwardly). The freedom to wear the bautà became the subject of countless restrictions and conditions, which had to be renewed at ever shorter intervals because no one seemed seriously concerned in adhering to them. A special magistrate for dress codes, the Magistrato all Pompe, was founded in 1514. The mask also presented a particular challenge for the secret police because it facilitated the clandestine transportation of weapons, as well as surreptitious changes of gender identity. ${ }^{13}$

It is no surprise, therefore, that the Venetians understood well that, in addition to their exotic goods from all over the world, their knowledge of human beings was a valuable means of power-with its own particular sellby-date. Consequently, they developed techniques to collect, examine, 
stretch, mix, weigh, exchange, sell, or buy that knowledge profitably. No individual piece of information would ever be taken at face value, but would become the subject of an intricate procedure of examination. Thus, in analogy to the commodity business, businesses dealing with knowledge began to flourish-services especially designed to counteract the easily perishable nature of knowledge and the fragility of cunning, using secrecy and person profiling. Participation of the many was not desired here.

\section{Why the Patrician Republic and the Police State Were Mutually Dependent in Venice}

Just one floor above the Maggior Consiglio was an elaborate architecture of secret passages, false wall panelling, torture and denunciation. The archives of the Doge's Palace were no less meticulous than those of the Vatican, despite the complete lack of religious zeal. They gathered not only folkloristic, but concise, applicable knowledge regarding foreign peoples. Simultaneously, they worked to acquire more knowledge about the predilections of their own noble families than a present-day Facebook 'friend' could even imagine.

Management of the Doge's Palace functioned, as Ursula Krechel's award-winning novel Landgericht (2012) describes, as

[...] a cave, a beehive, chamber to chamber, [where] from wall to wall people would be punished, and prosecuted [...], witnesses would be channelled into chambers, interrogated, defended.

The non-public part of the Doge Palace,

vibrated, $[\ldots]$ lived, $[\ldots]$ crushed, and in the end spat out judgments. It was a large, oiled machine. You would put your hand in the mouth of truth, and it would come out, bitten, scratched, bloodied. Or it would have remained, miraculously, just as uninjured as before. You had been released for lack of evidence. $^{14}$

In fact, there was a 'mouth of truth' in all public places in Venice but, in 1797, when Napoleon and his troops invaded the city during their Italian campaign, they could not distinguish it from denunciation. The bocce di leone were publicly displayed letter boxes for complaints, especially designed to prompt the citizens of Venice to remain vigilant over misuse 
and corruption. The inscription was always the same. It called for the written denunciations of anyone found suspicious of granting privileges, or of speaking cryptically in order to obscure the 'true interest' of their intentions.

However, the rules stated that any anonymous such letters were to be destroyed and left unread. A denunciator was required to sign with their name. It was only after an in-depth investigation, and if several complaints were collected around a given suspect, that a possible prosecution was made. The denouncer would also be prosecuted if what he claimed proved to be false; if his suspicion was confirmed, on the other hand, then his name would remain undisclosed to the public.

When, in 1797, the French attacked the Venetian Republic and its institutions - forcing the 120th Doge to abdicate-one of the first things they destroyed, in order to break the power distribution amongst noble families, was not only the only copy of the handwritten Golden Book, but they also demolished and mutilated the lions' mouths. Most importantly, however, was their forbidding of the wearing of masks in public under any circumstance. Their intention was to crush the symbols of an autocratic police and spy state, which no longer belonged in the century of enlightenment. Yet, without knowing it, in so doing, they hit the logistic heart of the Venetian power distribution, which did not organize participation and exclusion by reference to different groups of people or different classes, but rather, assigned both to the same people as equals among equals. Corruptible nobles, merchants and citizens were treated equally, and only tamed by institutional wisdom and clever procedures, not by reason, insight or deliberation.

The patrician republic and its police state were inseparable in Venice, just as the black bautà was to the white larva (volto), and just as inclusion and exclusion, strict secrecy and the greatest possible participation applied, not to different people and different things, but to everyone and everything equally. In the republic's self-conception, the Grand Council (Maggior Consiglio), the Council of Ministers (Minor Consiglio), and the feared secret police - the Council of Ten-pursued similar tasks such as seeking to undermine corruption, but with different means. The primary task of the resulting police and spy state was to investigate high treason amongst patricians, like activities involving gunpowder and plotting (often made possible thanks to the use of the mask). Greatest possible participation, paired with a strategic use of the lottery system, had a similarly preventive effect on corruption as strict secrecy had among a constantly rotating staff. 
Their understanding of the fallibility of each individual led the Venetians to limit the power even of the unique jurisdiction of the Council of Ten. Measures were put in place to undermine corruption: limited terms were implemented with yearly elections, the participation of the Doge and his six independent consultants (consiglieri) was required, the presence of 'avogadori de comùn' (attorney general) was necessary to testify to the legality of the secret ballot. The Council of Ten also elected three chairmen (capi), who were compelled to rotate every month on their own terms and whose names were kept strictly secret. No patrician family was allowed to send forth more than a single member to this council at any given time. And, as a precautionary measure in especially politically charged cases, the investigating capi were even locked up in the Doge's Palace to prevent any influence from outside.

\section{The System of Overlapping Competences}

The republic had its doctrines, which historians of the enlightenment mistook for paranoia. In the course of the trial against the Doge Marino Faliero for treason in 1355 , the Council of Ten was flanked by a further council, the zonta (the Council of Twenty). This was twice as strong and equipped with similar competences so that, for instance, controversial death sentences would be shouldered by thirty, rather than just ten people. Consequently, both magistrates began to keep each other in check, developing a curious system of balances between rivalling councils. Thus, the Council of Ten and the Council of Twenty gradually developed into double committees, which, over time, claimed all sorts of overlapping competences for themselves: state acquisition, secret police, chancellery of the Doge, war ministry, morality police; thus, controlling the alms of the cloisters, the health of the prostitutes, the ban on public duels, masks and masking habits, fun in the street theatres, and so on.

It took centuries for the Great Council and the Senate to undo these double structures. Indeed, it was not until 1644 that the zonta was disbanded, for the Venetian patricians soon got the hang of it, with their mandates limited in time and the obligatory breaks before entering into a new office; if dysfunctional dynamics could not be resolved (such as dubious power struggles between certain noblemen), then certain offices and institutions would simply be doubled up. The Venetian rules of conduct, to which the serenissima owed its proverbial serenity, was thus as follows: Political conflicts can be defused by means of targeted, institutionally 
anchored competence overlaps. This is achieved by temporarily doubling up a particular office with rotating staff. The gist is to create mirror councils that are mutually interrelated and keep each other in check; in other words, by undermining and ridiculing each other, say, by arriving at opposite conclusions to the same simple question as, for instance, with regard to the question of whether or not to allow the Venetian society mask (bautà) to be worn in public on a particular day.

And so, it is no wonder that Casanova was once condemned, once helped to escape, and then declared honorary citizen of Venice, before being sent to France and Bohemia as an informer. In the end, he left his birthplace, full of contempt forever. To the Venetian nobili, to which he never fully belonged, he devoted a pamphlet in 1782: Né Amori, né Donne ('Neither Love, nor Women').

In the twenty-fifth chapter of his posthumous recollections (Histoire de ma Vie, in the French original) - after having become acquainted with forms of government in Austria-Hungary, Prussia and France-Casanova, with a sideways kick to his home town, declared:

Like all worm-bitten institutions, it continues to exist. Most of today's governments resemble those old dams whose foundations are completely decayed, and which remain in their place only by virtue of their own weight. $^{15}$

\section{Notes}

1. The term bautà literally meant the black hood, but soon became an umbrella term for all the components of the costume.

2. This limitation doesn't simply mean that the 3500 members of noble families rule over 136,500 others. We will soon see why.

3. The historian Renan therefore sees at work an 'Averroean rationalism of Paduan scholars'. [Author's translation]-Ignatio Toscani: Die venezianische Gesellschaftsmaske. Ein Versuch zur Deutung ibrer Ausformung, ihrer Entstehungsgründe und ihrer Funktion. Inaugural-Dissertation der Universität des Saarlandes, Saarbrücken 1972, p. 108.

4. Casanova's nom de guerre as spy is Antonio Pratolino.-Giacomo Casanova: The Story of my Escape from the Prison of the Republic of Venice, otherwise known as 'The Leads', written in Dux in Bohemia in 1787. Translated from the French edition by Andrew L. Lawston, Kindle Edition 2014.

5. After the first plague in 1348 had extinguished whole families, and the Genoese had given up the siege of Chioggia in 1381 (with the help of 
all Venetian citizen), the total figure of noble families was increased at once by 30 bourgeois families, the case nuove. Later, after significant losses against the Turks in the 17th century, the case novissime gained access to peerage by paying large amounts of money to the Venetian state. Over the centuries, the number of male nobles over 30 years of age and with families with at least two children-in other words, those qualified to elect the Doge and all other offices-varied between 1000 and 2746 .

6. Cf. Insa Holst (2007) Handel im 15. Jahrhundert: Der Kaufmann von Venedig, in: Venedig (810-1900): Macht und Mythos der Serenissima, GEOepoche Nr. 28, (Hamburg), 48-63.

7. Wolfgang Wolters (2010) Der Dogenpalast in Venedig. Ein Rundgang durch Kunst und Geschichte, (München).

8. Unfortunately, in the National Gallery of London, the bautà is still falsely labelled as a 'typical Venetian carnival mask'. Nothing could be more wrong.

9. "The social role is not an "arbitrary corset of behavior" but a distinct social element $[\ldots]$. It thus stars at every "seam", where the individual meets his social milieu, that is, where man and the impersonal system of relationships merge into a role which man has to play in society' [Author's translation]-Toscani (1972) (typo-script in German), p. 99.

10. The rhinoceros was exhibited as a fierce beast, as her keeper carries a whip and shows a horn of a bull instead. But alongside the disguised Venetian nobles, it quickly becomes apparent that with her ears flattened at her head, Clara is really just a badly dressed, harmless ruminant.

11. Lorenzo de Monacis, as quoted by Eva-Maria Schnurr, in: 'Venedig: Die ganze Stadt ein Grab', in: Der Spiegel, May 30, 2012. See, http://www. spiegel.de/spiegel/spiegelgeschichte/d-85776628.html. [Author's translation]

12. Ibid.

13. Originally reserved for the patricians, it was soon also worn by members of other classes, as well as by educational travellers (such as Goethe in 1786). Through the semi-transparent black gauze, anyone could tell a person's status by 'reading' the clothes that they were wearing underneath. However, it soon became fashionable to dress up under the bautà as well, like as a clergyman, for example, in order to enter into a convent of women without causing suspicion.

14. U. Krechel (2012) Landgericht, (Jung und Jung, Salzburg/Vienna), p. 58 .

15. Author's translation. For further reading, cf. Jörg-Uwe Albig (2007) 'Der Verführer, 1725-1798: Casanova', GEO Epoche-Venedig (810-1900): Macht und Mythos der Serenissima, 28, 142-156. 


\section{REFERENCES}

Ackroyd, Peter. 2009. Venice. Pure City. London: Chatto \& Windus.

Agamben, Giorgio. 1998. Homo Sacer. Sovereign Power and Bare Life. Trans. Daniel Heller-Roazen. Stanford: Stanford University Press.

Albig, Jörg-Uwe. 2007. 'Der Verführer, 1725-1798: Casanova' ('The Seducer, 1725-1798: Casanova'*). GEO Epoche - Venedig (810-1900): Macht und Mythos der Serenissima 28: 142-156.

Casanova, Giacomo. 2014. The Story of My Escape: From the Prisons of the Republic of Venice Otherwise Known as the 'Leads'. Trans. Andrew Lawston, Kindle edition. North Charleston: CreateSpace Independent Publishing Platform.

Crowley, Roger. 2011. City of Fortune. How Venice Ruled the Seas. New York: Random House.

Directorate of the Doge's Palace. (ed.) 1959. Der Dogenpalast. Kunsthistorischer Führer. Venice: Officine Grafiche Ferrari.

Ferrari, Simone. 2010. The Doge's Palace in Venice. Milan: Skira.

Gualdoni, Flaminio. 2010. [Pietro] Longhi. Milan: Skira.

Holst, Insa. 2007. Handel im 15. Jahrhundert: Der Kaufmann von Venedig.' ('Trade in the 15th Century: The Merchant of Venice'*). GEO Epoche - Venedig (810-1900): Macht und Mythos der Serenissima 28: 48-63.

Krechel, Ursula. 2012. Landgericht. Roman, 58. Jung und Jung: Salzburg and Vienna. Norwich, John Julius. 1977/2012. A History of Venice. London: Penguin.

Rademacher, Cay. 2007. "Spanische Verschwörung” (1618): Tod in der Lagune. ('Spanish Conspiracy' (1618) Death in the Lagoon*). GEO Epoche - Venedig (810-1900): Macht und Mythos der Serenissima 28: 110-122.

Rancière, Jacques. 1999. Disagreement: Politics and Philosophy. Trans. Julie Rose, Minneapolis: University of Minnesota Press.

- 2004. The Politics of Aesthetics. Trans. Gabriel Rockhill, London: Bloomsbury. (Le partage du sensible. Esthétique et politique, Paris 2000).

Strempel, Johannes. 2007. Flottenbau, um 1570. GEO Epoche - Venedig (810-1900): Macht und Mythos der Serenissima 28: 94-104.

Toscani, Ignazio. 1972. Die venezianische Gesellschaftsmaske. Ein Versuch zur Deutung ihrer Ausformung, ihrer Entstehungsgründe und ihrer Funktion ('The Venetian Society Mask. An Attempt to Interpret Its Formation, Origins and Function'*). Inaugural Dissertation for a Doctorate in Philosophy, Saarbrücken. (Typoscript).

von Hadeln, Detlev Freiherrn. 1911. 'Beiträge zur Geschichte des Dogenpalastes' ('Contributions to the History of the Doge's Palace'*). Jahrbuch der Königlich Preussischen Kunstsammlung 32: 1-33.

Wolters, Wolfgang. 2010. Der Dogenpalast in Venedig. Ein Rundgang durch Kunst und Geschichte ('The Doge's Palace in Venice. A Tour of Art and History'*). Munich: Deutscher Kunstverlag.

*Translation by author 
Open Access This chapter is licensed under the terms of the Creative Commons Attribution 4.0 International License (http://creativecommons.org/licenses/ by $/ 4.0 /)$, which permits use, sharing, adaptation, distribution and reproduction in any medium or format, as long as you give appropriate credit to the original author(s) and the source, provide a link to the Creative Commons licence and indicate if changes were made.

The images or other third party material in this chapter are included in the chapter's Creative Commons licence, unless indicated otherwise in a credit line to the material. If material is not included in the chapter's Creative Commons licence and your intended use is not permitted by statutory regulation or exceeds the permitted use, you will need to obtain permission directly from the copyright holder.

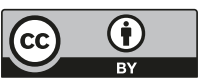

